\title{
The Structure of Verbless Sentences in Northern Kurdish
}

\author{
Aveen Mohammed Hasan, (PhD) \\ University of Zakho, Kurdistan-Region, Iraq
}

doi: 10.19044/esj.2017.v13n23p86 URL:http://dx.doi.org/10.19044/esj.2017.v13n23p86

\begin{abstract}
In the study of syntax, a special attention is given to the verb as the main constituent in the structure of the predicate. However, there exists some constructions in which a noun, adjective or an adverb are the main constituents in the predicate. In Kurdish literature, there is a debate on the analysis of these verbless constructions. On one hand, they are considered nominal sentences which do not contain a verbal element. On the other hand, they are considered small verbal sentences in which the agreement markers on the predicate act as verbal element. The study is an attempt to analyse the structure of these verbless constructions within the framework of minimal program (Chomsky, 1995) in one of the widely spoken variety of Kurdish, Northern Kurmanji, Bahdinani subdialect. It contributes to resolve the existent debate in Kurdish linguistics concerning the structure of these constructions. Additionally, it contributes to the typological variation in the syntactic properties of these constructions in Kurdish.
\end{abstract}

Keywords: Verbless sentences, Northern Kurdish, present tense, past tense, future tense

\section{Introduction}

In Kurdish, as in other languages such as Arabic, Hebrew, Russian, in the present tense there exist some sentences which are characterised by the absence of an overt verbal copula. In syntax, these sentences are defined as verbless sentences (Al-Horais, 2006). For example, sentence 1 is in present tense and is absent from an overt verbal copula. Throughout the paper, the Kurdish examples are written using the Latin Kurmanji writing system ${ }^{1}$, their glosses and their meanings in English are given in rounded brackets.

${ }^{1}$ Kurdish is written in different writing systems, namely modified Arabic, Latin Kurmanji and Cyrillic. Even in the symbols within these systems differ between the scholars and they do not contain symbols for a lot of sounds which are also identified in Kurdish. This study 
1- ez kurdim.

I Kurd- $1^{\text {st }}-$ SING

(I am a Kurd.)

However, in the past and future tenses the case is different. The presence of an overt copula is obligatory, as in examples 2 and 3.

2- ez kurd bum

I Kurd be- $1^{\text {st }}-$ SING

(I was a Kurd.)

3- ez dêbime kurd

I FUT-be- ${ }^{\text {st }}$-SING Kurd

(I will be a Kurd.)

In the Kurdish syntactic literature, there is a big debate about the existence and non-existence of verbless sentences (Mohammed, 1974). On one hand, a sentence like:

4- ez mirovim.

I human- ${ }^{\text {st }}$-SING

(I am a human being.)

can be analysed as a verbal sentence in which the personal pronoun ending $\langle i m\rangle$ in the noun <mirov $>$ is analysed as a copula indicating present tense or present tense copula. In other words, it is claimed that the personal pronoun $\langle i m\rangle$ in this sentence is similar to $\langle a m\rangle$ in English in that it represents the present tense state of verb $\langle$ to $b e\rangle$ in Kurdish. Thus, all the underlined personal pronoun endings in <ez mirovim, em mirovin/ $\underline{i n}$, tu mirovî, hun mirovin, ew mirove and ew mirovin > represent the forms of verb to be in present. This view is adopted by Amin (1976) and Thackston (2006). This claim can be criticised in that these endings are personal pronoun clitics and they do not have any verbal features. Additionally, these endings function as agreement morphemes of person and number with the subject and are attached to the verbs also in verbal sentences that contain lexical

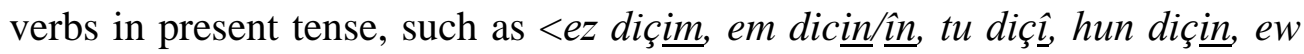
diçe and ew diçin>. Now if these endings are verbs as stated above, so how these sentences can be analysed?

On the other hand, verbless sentences such as 4 can be analysed as nominal sentences in that there is no verb in the sentence, but it consists of a subject, a complement and an agreement marker (Mohammed, 1974). The complement can be a noun, adjective or adverb.

Within the framework of minimal program (Chomsky, 1995), this paper aims to contribute to resolve the present debate in the Kurdish literature concerning the structure of these clauses. Finally, this study,

adopts the Latin Kurmanji writing system (Hasan, 2012) and a list the symbols is presented in the appendix. 
following Benmamoun (2000), suggests that verbless sentences are fullfledged clauses that exhibit the same properties of tense clauses. The study is based on data produced by native Bahdinani Kurdish which are taken from every day conversations and written texts. Before the actual analysis, in the next sections a brief picture of the minimalist theory and the structure of the Kurdish verbless sentences will be presented. In section 4, a review of previous literature on verbless sentences in other languages is presented. The analysis of tense (present, past and future) in Kurdish is discussed in section 5 with a particular focus on the present tense. Finally the main conclusions of the study are presented in section 6 .

\section{The minimalist theory}

According to the minimalist theory (Chomsky, 1995), the grammar consists of a lexicon and computational system. The lexicon contains familiar lexical entries: verbs, nouns, adjectives and pre or postpositions. The semantic selection and thematic properties of these lexical items specify the argument structure of a head, i.e. these indicate the number of arguments the head licenses and their semantic roles. For example, the verb <give > assigns an agent role, a theme role and a goal/recipient role to <John, a book and Mary> respectively in a sentence such as:

5- John gave a book to Mary.

Chomsky adds that an argument must receive a semantic role ( $\theta$ role) from a lexical head ( $\Theta$-marking) and the position in which a $\theta$-role is assigned is a $\theta$-position. In order to make an argument visible for $\theta$-marking, it should be assigned a case. In the theory of case, every argument has an abstract case realised overtly depending on the morphological properties of the language.

On the other hand, the computational system consists of structurebuilding machinery and principles of derivational economy. The grammar has different syntactic levels of representation: Logical Form (LF), Phonological Form (PF) and D-Structure. LF is the level of representation that interfaces with the conceptual-intention system. PF is the interface with the articulatory-perceptual system. The D-Structure relates the computational system and the lexicon. These levels are related through the mediation of an intermediate level of S-Structure. The relations among these levels are directional, i.e. they are constructed as a mapping of one level to another. Each of these levels consists of atomic elements (primes) and objects constructed from them by concatenation and other operations. The primes constitute the terminal string of a phrase marker which are drawn from the lexicon or they are projected from the heads by operations of the computational system. Elements that do not project further are called maximal projections. For example, a noun phrase (NP) is the maximal 
projection of its head noun $(\mathrm{N})$. The two basic relations of a phrase maker are domination and linearity. For example in the phrase marker (6) (from Chomsky, 1995: 34):

6-

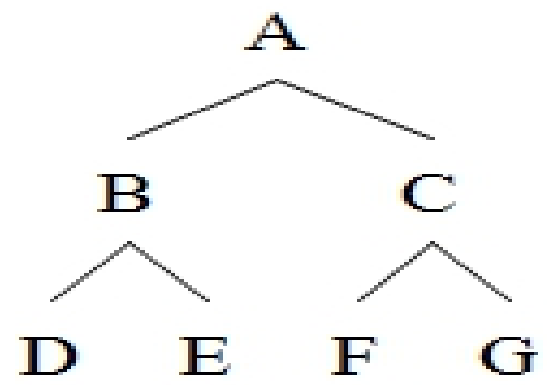

A dominates all the categories (nodes): B, C, D, E, F and G. B precedes $\mathrm{C}, \mathrm{F}$ and $\mathrm{G}$ and so on. Additionally, if $\mathrm{X}$ is a head, its sister is its complement. Thus, $\mathrm{E}$ is the complement of $\mathrm{D}$. Here in a language if heads precede their complements, the language is right-branching such as English, while if the heads follow the complements, the language is left-branching such as Japanese.

Another important concept in the grammar is command. Thus, ccommand is when an element is not dominating another. For example, in (6) $\mathrm{B}$ c-command $\mathrm{C}, \mathrm{F}$ and $\mathrm{G}$. While, m-command is restricted to maximal projection when two elements are dominated by the same element. For instance, in (6) A dominates B and C, so we can say that B m-commands C.

There are essentially two kinds of operations in minimalism: overt and covert operations. Overt operations occur before the level of PF; covert operations occur after spell-out on the way to LF. The determination of when an operation occurs (i.e. overtly or covertly) is a function of languagespecific conditions specified in a language's inflectional morphology. Additionally, in the phrase structure, every head $\left(\mathrm{X}^{\circ}\right)$ projects to a maximal category (XP); it may take a complement (sister to head) which must be phrasal. It may also have a specifier (sister to unit of complement and head). The terminal nodes in trees are inserted with inflectional features attached. These inflectional features must be checked against an inflectional head to insure they match other inflectional features in the sentence. This feature checking may occur via head-to-head-movement (in the case of predicates) or via movement to the specifier of a phrase (in the case of arguments). Movement within the syntax (both overt and covert) is also constrained by the minimality constraint of shortest move. Shortest move requires that all movement take the shortest path available to it. Chomsky ties movement of objects to the head-movement of the verb. Movement of the verb to an inflectional head allows an object NP to move to the specifier of that head. 
Thus, Chomsky (1995: 60) proposes the following underlying architecture for the clause:

7-

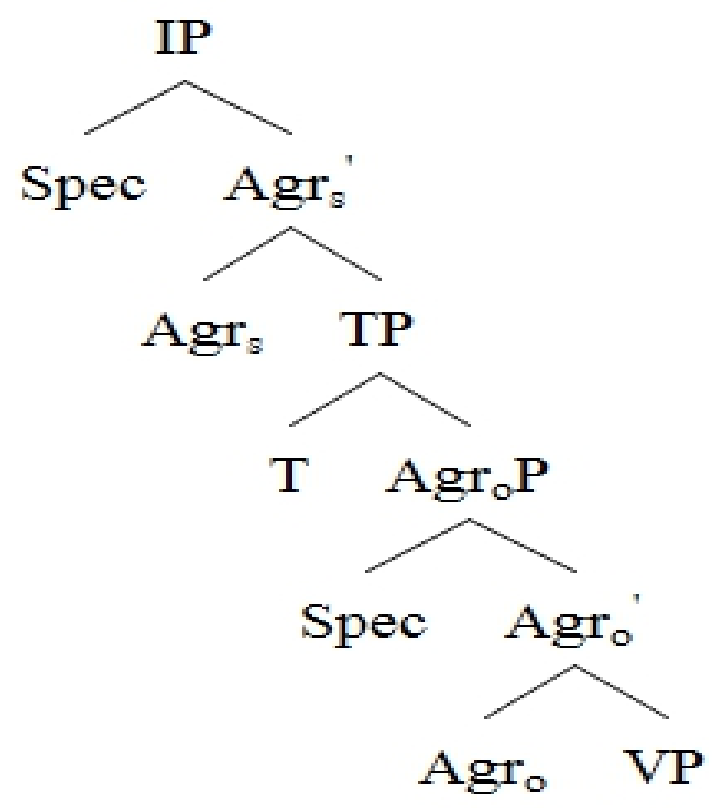

The clause consists of an inflectional complex (IP) and a verb phrase (VP) shell. The VP contains the verb, its complement, and its subject. The inflectional complex consists of two non-distinct agreement phrases (AgrPs), one for the subject agreement and subject case and the other for the object agreement and object case, and a tense phrase (TP). Chomsky has suggested that nominative and accusative cases are realized in a parallel manner, via movement of the arguments to positions within the inflectional complex. Specifically, it is suggested that all agreement and structural case is the realization of a specifier/head relationship with an appropriate functional (Agr) head. As the agreement heads are non-distinct, the case with which each is associated is determined by the nature of the element which adjoins to it. The accusative case, being in some sense a verbal attribute, must be realized in the specifier/head relationship with the complex head [V, AgrO] derived via the first step of the head-to-head-movement of the verb when the verb is transitive. By similar logic, head-movement of Tense (T) to AgrS will create the complex head [T, AgrS], and nominative case will be realized in a specifier/head relationship to this head.

\section{The structure of verbless sentences in Kurdish}

From the preceding data, it is obvious that verbless sentences consist of a subject and a non-verbal predicate. The subject could be a pronoun, a 
noun or a noun phrase. The non-verbal predicate is classified into three categories: noun as in (4), adjective in (8) and adverb in (9 \& 10).

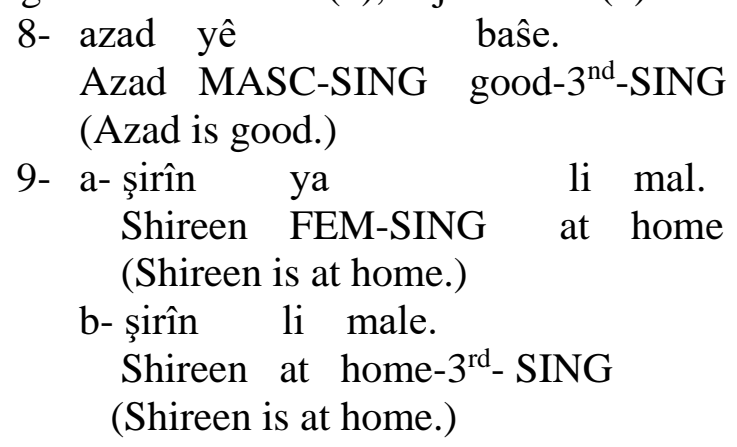
10-a- azad u şirîn yêt li mal.
Azad and Shireen PL at home
(Azad and Shireen are at home.)

b- azad u şirîn li malin.

Azad and Shireen at home- $3^{\text {rd }}-\mathrm{PL}$

(Azad and Shireen are at home.)

As for agreement, it can be observed that the agreement between the subject and the predicate in verbless sentences is full agreement: the predicate carries all the features that the subject has, i.e. number, person and gender. However, the type of agreement depends on the syntactic category of the predicate. When the predicate is a noun, the agreement markers of person and number appear on the nominal predicates. The person and number agreements (presented in 11) are realised by suffixes on the non-verbal predicate (or on the verb in verbal predicates).

\begin{tabular}{|c|c|c|}
\hline & singular & plural \\
\hline $\mathbf{1}^{\text {st }}$ & im & in $/$ in \\
\hline $\mathbf{2}^{\text {nd }}$ & $\hat{\imath}$ & in \\
\hline $\mathbf{3}^{\text {rd }}$ & $\mathrm{e}$ & in \\
\hline
\end{tabular}

While, when the predicate is an adjective, the gender markers must occur between the subject and the predicate in addition to the person and number markers on the adjectival predicate. The gender markers include $<$ yê $>$ for masculine, $<$ ya $>$ for feminine and $<$ yêt $>$ for plural. In adverbial predicates in NK two possibilities exist either person is indicated ( $9 \mathrm{~b}$ and $10 \mathrm{~b}$ ) or gender (9a and 10a) but not both features. However, the constructions in which gender is only indicated is the more common one.

\section{Literature review}

There are different analyses of the verbless sentences in the literature on other languages. In Arabic, for example, there exists three descriptions of these structures. One analysis states that there is a verbal copula in verbless sentences but it fails to lexicalise either because it has undergone deletion 
(Bakir, 1980 cited in Abu-joudeh, 2013) or it is phonologically null (FassiFehri, 1993). Fassi-Fehri (1993: 87) suggests that the copula is present at Dstructure in verbless sentences but it is not lexicalised because it carries an unmarked $\mathrm{T}$ feature, i.e. [-past], while in verbal sentences, the copula bears [+past] $T$ feature which forces it to be realised phonologically. This suggestion implies that there is a functional projection which hosts tense. However, this assumption has some problems. It cannot, for example, account for the fact that the predicate where the copula is phonologically null is marked with a nominative case while when it is lexicalised it bears an accusative case (as in 12 and 13 respectively, from Abu-joudeh, 2013: 210).
11- az-zaww-u zamiil-un
the-weather-nom nice-nom
(The weather is nice.)
12-kana az-zaww-u
was. $3 \mathrm{~ms}$ the-weather-nom nice-acc
3amiil-an

(The weather was nice.)

The second analysis treats verbless sentences as matrix small clauses with no functional projection (Mouchaweh, 1986 for Arabic and adopted by Rapport, 1987 for Hebrew). Mouchaweh (1986 cited in Abu-joudeh, 2013) claims that verbless sentences do not have any functional projection. They only contain the lexical projection of the predicate and the subject takes the specifier position of this projection. His claim can be illustrated in the Dstructure presented in (14 from Abu-joudeh, 2013: 211). Thus, it indicates that there is no functional projection above the lexical projection to host tense.

$13-$

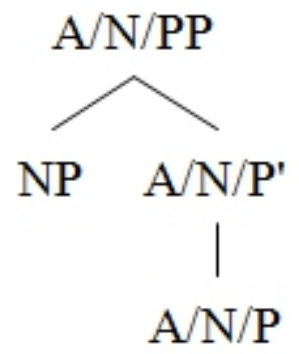

Al-Horais (2006) also assumes that there is no V and hence no VP in verbless sentences. He claims that the relevant construction has two alternatives to express the present tense: one is achieved without a verb and the other with a verb (copula) <ya-kuun> inflected for tense.

The third analysis proposes that verbless sentences contain a functional projection that is marked for tense but no verbal copula (Benmamoun, 2000). Benmamoun (2000) analyses these constructions as full-fledged clauses that show the same properties of tensed clauses. One 
strong argument for his claim is based on the fact that in Arabic the subject in these constructions surfaces with nominative case, as in (15 from Abujoudeh, 2013).

14- t-t- aalib-u fii l-maktabati

the-student-nom in the-library

(The student is in the library.)

This can be explained that there is a $\mathrm{T}$ head that checks nominative case. To illustrate the absence of verbal copula in the verbless sentences, Benmamoun posits that in the present tense the $\mathrm{T}$ head has different categorical feature specifications from the past and future tenses. The present tense in verbless sentences is specified as $[+\mathrm{D}]$ only in contrast to the past and future tenses which are specified for both $[+\mathrm{D}]$ and $[+\mathrm{V}]$ features. Because the present tense is not specified for a $[+\mathrm{V}]$ feature, the copula is not needed to check this feature. While, the $[+\mathrm{D}]$ feature can be checked by the subject. Benmamoun illustrates the structure of these construction as in 16 (from Benmamoun, 2000: 49):

$15-$

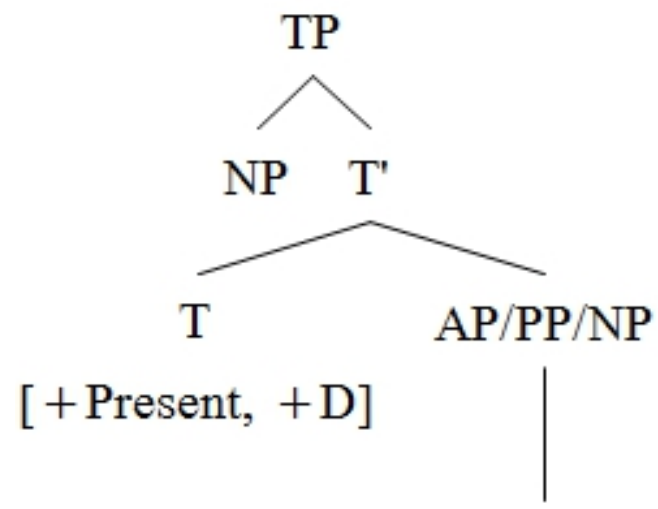

$\mathrm{A} / \mathrm{P} / \mathrm{N}$

Benmamoun's claim is further supported by two additional (related) arguments presented by Hazout (2010) in his interpretation of Hebrew's verbless sentences. The arguments are based on the distribution of atmospheric and predicative interpretations of certain predicates which depends on the (semantic) nature of the subject permissible in a given clausal structure.

Following Benmamoun (2000), we assume that Kurdish verbless sentences exhibit the same properties of tensed clauses. They are specified for $[+\mathrm{D}]$ feature only and there is no need for a copula since it is not specified for a $[+\mathrm{V}]$ feature. The following sections present arguments to support this claim. 


\section{Tense in Kurdish}

Chomsky (1995) proposes that tense is specified for two categorical features: the $[+\mathrm{V}]$ feature and the $[+\mathrm{D}]$ feature. The feature $[+\mathrm{V}]$ determines the interaction between tense and the verb, whereas the feature [+D] determines its interaction with the subject (Extended Projection Principle).

However, it is conceivable that in some languages the tense can be specified for both or only one of these two features. In Arabic and Hebrew in the present tense, for example, the $\mathrm{T}$ head does not have a $[+\mathrm{V}]$ feature, but only $[+\mathrm{D}]$ feature. In English and French, by contrast, the present tense is specified for the $[+\mathrm{V}]$ feature and the $[+\mathrm{D}]$ feature.

Similar to Arabic and Hebrew, Kurdish verbless sentences contain a functional projection marked for tense because the present tense meaning is understood by native speakers but they have no verbal copula. Thus, we assume that in the present tense in Kurdish, tense is specified only for [+D] feature, while the past and future have the $[+\mathrm{V}]$ feature and the $[+\mathrm{D}]$ feature, as shown in 17.

$\begin{array}{ll}\text { 16- Present } & {[+\mathrm{D}]} \\ \text { Past } & {[+\mathrm{D},+\mathrm{V}]} \\ \text { Future } & {[+\mathrm{D},+\mathrm{V}]}\end{array}$

In the following subsections, arguments are presented to support this assumption.

\section{The present tense}

As indicated above, the major characteristic of the present tense in Kurdish is that it does not require a verbal predicate. Consider the following examples:

17- azad mamostaye.

azad teacher- $3^{\text {rd }}-$ SING

(Azad is a teacher.)

18- azad yê baŝe.

azad MASC-good- $3^{\text {rd }}-$ SING

(Azad is good.)

19- a- azad yê li mal.

azad MASC-at-home

(Azad is at home.)

b- azad li male.

azad at-home- $3^{\text {rd }}-$ SING

(Azad is at home.)

In these examples, there is no verbal head to check the $[+\mathrm{V}]$ feature of the present tense. Here we propose that these constructions contain a functional projection specified for present tense but there is no copula. In 
other words, the present tense is $[+\mathrm{D}]$ only which can be fulfilled by the subject.

In Kurdish, the subject could be definite or indefinite in the verbless sentences in contrast to many other languages such as Arabic, Hebrew (Rapoport, 1986) and Russian in which indefinite subjects are not acceptable in verbless constructions. Consider the following examples:

20-mamosta yê li mal.

teacher/def. MASC- at-home

(The teacher is at home.)

21-mamostayek yê li mal.

teacher/indef. MASC- at-home

(A teacher is at home.)

It is observed that when the indefinite article is used the sentence is turned to an existential sentence and there is a difference in meaning between the two sentences. The first indicates that (the teacher is at home), while the second indicates that (there is a teacher at home). Thus, verbless sentences that have a common noun subject with an indefinite article have the existential meaning. As for predicate nouns, Kurdish allows any article in nominal predicates, but its absence is preferred. For example, in

22-karwan qotabiye

Karwan student- $3^{\text {rd }}$-SING

(Karwan is a student.)

The use of the noun <qotabi> without any article is the preferred

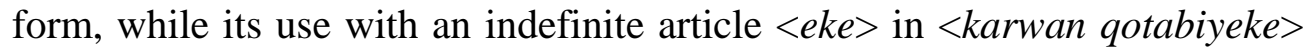
is also acceptable. In this respect, Kurdish behaves similar to Romance languages such as French and Italian in which the realisation of the articles in the predicate nouns is optional (Rapoport, 1986).

As mentioned in section 3, verbless sentences involve marking of gender, number and person. The person and number are obligatory features in nominal and adjectival predicates, while person is optional in adverbial predicates. Gender is only indicated in adjectival and adverbial predicates by the use of gender markers <ye and $y a>$, but not in nominal predicates. These gender markers are parts of the predicate not the subject and the evidences for that are: they follow the negation (24), they are not deleted in the case of subject deletion (25) and they follow adverbial modifiers (26).

23- azad ne yê baŝe.

azad NEG-MASC-good-3 ${ }^{\text {rd }}-$ SING

(Azad is not good.)

24- yê baŝe.

MASC-good- $3^{\text {rd }}-$ SING

(He is good.)

25-jiyan gelek ya jane. 
Jiyan very FEM-beautiful-3 ${ }^{\text {rd }}-$ SING

(Jiyan is very beautiful.)

It can be observed that subject deletion or pro-drop is possible in nominal, adjectival and adverbial predicates in all tenses. This is due to the presence of person features which are necessary for the identification of the referential null subject.

Furthermore, the gender markers $\langle y \hat{e}$ and $y a>$ cannot be considered verbs because they also appear in verbal sentences, as in:

26- azad yê baŝbu.

azad MASC-good-was- $3^{\text {rd }}-$ SING

(Azad was good.)

Concerning why gender markers are not indicated in noun predicates, we can say that the identity relation between the two nouns in the subject and predicate positions is assigned using number and person agreements only because the entity denoted by the subject and the predicate are identified as one or the same. Thus, the sentence 18 can also be produced as:

27- mamosta azade.

teacher azad- $3^{\text {rd }}-$ SING

(The teacher is Azad.)

As for the two structures of agreement in adverbial predicates (20a with gender and number markers and $20 \mathrm{~b}$ with person and number markers), it seems that they are speaker variations for the two are used regularly by NK speakers. However, which structure is the most common needs to be investigated in a follow up study. This is found only in present tense because in past and future gender is not indicated, i.e. only person and number are shown, as in 29 and 30. Also, in negation, gender disappears and person is shown as in 31:

28-azad li malbu.

azad at-home-was- $3^{\text {rd }}$-SING

(Azad was at home.)

29- azad dê li malbît.

azad FUT-at-home-be- $3^{\text {rd }}$-SING

(Azad will be at home.)

30- azad ne li male.

azad NEG-at-home- $3^{\text {rd }}-$ SING

(Azad is not at home.)

Thus, since verbless structures in Kurdish involves marking of person in all types of predicates and since person marking is a typical strategy of verbal predicate formation (Wetzer, 1996), we argue that verbless structures are verbal sentences not nominal. Wetzer (1996: 192) states that 'in a given language, verbal predicates can be distinguished from nominal predicates because verbs, not nouns are marked for person'. Thus, in Kurdish since 
verbless predicates such nouns, adjectives and adverbs are marked by person markers which are used to cross-reference the subject that is found in the case of intransitive verbs, these predicates are considered verbal not nominal, as in:

$31-$

ez kurdim (I am a Kurd.) ez diçim (I go.)

ez yê başim (I am good.)

ez li malim (I am at home.)

Thus, the sentences 18 and 19 are distinguished from nominal phrases by the presence of the person marking. The following sentences are considered nominal phrases because they are characterised by the absence of person agreements:

32- azadê mamosta.

azad-MASC teacher-SING

(Azad who is a teacher.)

33- azadê baŝ.

azad MASC good-SING

(the good Azad)

Furthermore, verbless sentences cannot be treated as small clauses which depend on the matrix clause for their temporal reference. In other words, when they are embedded under a tensed matrix clause, they do not necessarily have the same temporal reference as the matrix tense, but they have their own present tense interpretation. The example presented in 35 shows that the matrix sentence has a past tense interpretation <min gut $\rangle$ while the embedded verbless clause has a present tense interpretation $<e z$ kurdim>.

34-min gut ez kurdim

I say-PAST I kurd- ${ }^{\text {st }}$ SING

(I said I am a Kurd.)

Another argument in favour of the claim of functional projection of tense is sentential negation. In NK, negation is realised by the proclitic $\langle n e\rangle$ which is usually stressed and positioned before the complement (Thakston, 2006), as in:

35- ez ne kurdim

I NEG kurd- $1^{\text {st }}$ SING

(I am not a Kurd.)

36- ez ne yêbaŝim.

I NEG MASC-good- ${ }^{\text {st }}$ SING

(I am not good.)

37- ez ne li malim.

I NEG in-home- ${ }^{\text {st }}$ SING

(I am not at home.) 
The verbless sentences are specified for tense feature that is why they are analysed as TPs that dominate non-verbal predicates. Let us assume that tense and negation occupy different projections and the tense projection dominates the negative projection. The negative morpheme precedes the tensed verb which can be derived by moving the verb negation and then to tense. This can be illustrated in the following example:

$38-$

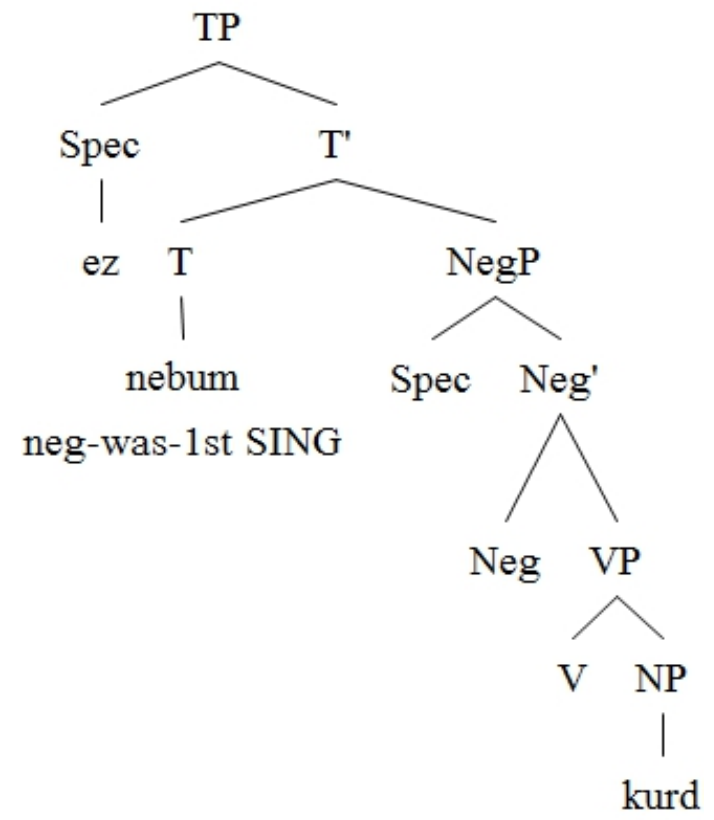

In verbless sentences, the non-verbal predicate can rise to negation, as in the following tree diagram in which the non-verbal predicate is a noun phrase:

39-

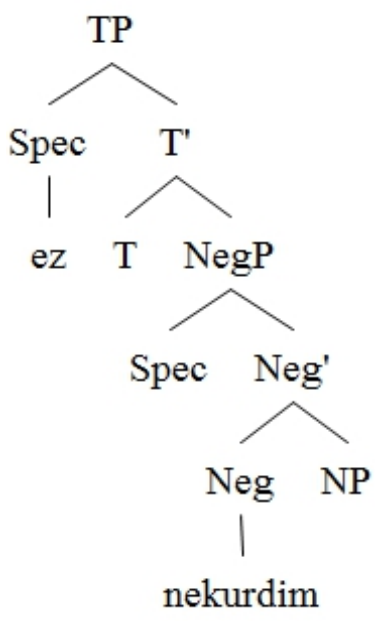


The same can be applied to other nonverbal predicates, i.e. the adjectival and adverbial. In these cases, the subject must precede the sentential negation to check the $[+\mathrm{D}]$ feature of the tense.

Finally, another argument in favour of the claim that there is no verbal copula in verbless sentences is that in Kurdish, as in Hebrew (Rapoport, 1986), there is no present tense conjugation of the verb <bun> (to be), as shown in 41. In contrast, Arabic (Al-Horais, 2006) has the present form of the copula <kan> which is the verb <ya-kuun>. Thus verbless sentences are only available in the present tense. The copular is found only in past and future tenses.

$40-$

\begin{tabular}{|c|c|c|}
\hline & past & future \\
\hline $\mathbf{1}^{\text {st }}$ SING & bum & dê bime \\
\hline $\mathbf{2}^{\text {nd }}$ SING & buyî & dê bîye \\
\hline $\mathbf{3}^{\text {rd }}$ SING & bu & dê bîte \\
\hline $\mathbf{1}^{\text {st }} \mathbf{P L}$ & buyîn & dê bîne \\
\hline $\mathbf{2}^{\text {nd }} \mathbf{P L}$ & bun & dê bine \\
\hline $\mathbf{3}^{\text {rd }} \mathbf{P L}$ & bun & dê bine \\
\hline
\end{tabular}

To conclude, in the present tense sentences in Kurdish, tense is specified only for $[+\mathrm{D}]$ feature and they are considered verbal not nominal because they show the characteristics of verbal constructions. This section presented different arguments in favour of this claim which are: 1) the identification of person, 2) they have their own present tense interpretation when they are embedded under a tensed matrix clause, 3) sentential negation and 4) that Kurdish verb <to be> has no present form. The following section examines the way case is marked in verbless sentences.

\section{Case marking in verbless sentences}

It is argued that all argument noun phrases in a sentence must receive case (Rapoport, 1987). In Hebrew nominal sentences, because they lack a verb which assigns case to the arguments, it is claimed that the agreement of the predicate can assign a nominative case to the subject noun phrase and thus mark a theta-role (Ibid). Rapoport adds that case marking is important for the visibility hypothesis: an element is visible for theta-marking only if it is case marked. Thus if an argument is not case marked then it cannot be theta-marked. Furthermore, he argues that for the predicate to assign case to the subject noun phrase, it should be adjacent to the subject and have agreement.

As for Hebrew, we argue that in Kurdish verbless sentences, the agreement on the predicate can assign nominative case because the agreement is part of the predication relation. When agreement is part of the 
predication, case is also a part and is assigned by the predicate along with the theta-role. Thus in the examples (18-20) above, the predicate is in a full agreement with the subject noun phrase and there is no other governor, then it assigns the noun phrase case.

\section{The past tense}

The past tense requires the presence of a copula which implies that it is $[+\mathrm{V}]$. The copula checks the categorical $[+\mathrm{V}]$ feature. Consider the following examples:

1- ez kurdbum.

I kurd-was- ${ }^{\text {st }}$ SING

(I was a kurd.)

2- ez yê baŝ bum.

I MASC-good-was- ${ }^{\text {st }}$ SING

(I was good.)

3- ez li mal bum.

I at-home-was- $1^{\text {st }}$ SING

(I was at home.)

In these examples, the subject agreement suffix on the copula indicate that it is $[+\mathrm{D}]$ not a realisation of the past tense.

\section{The future tense}

Future also appears to be $[+\mathrm{V}]$ and $[+\mathrm{D}]$. It always requires the presence of a verbal copula to check the $[+\mathrm{V}]$ feature.

1- ez dê bime kurd.

I will-be- ${ }^{\text {st }}$ SING kurd

(I will be a kurd.)

2- ez dê baŝ bim.

I will-good-be-1 ${ }^{\text {st }}$ SING

(I will be good.)

3- ez dê li mal bim.

I will-at-home-be- ${ }^{\text {st }}$ SING

(I will be at home.)

The agreement on the verb is a reflection of its $[+\mathrm{D}]$ feature. The future tense morpheme $<$ dê $>$ merges with the copula in the case of nominal predicate, while in case of adjectival and prepositional phrase predicate they are separated by the insertion of the adjective or adverb. Besides, it can be observed that gender marker is not indicated in adjectival and adverbial predicates in future. 


\section{Conclusion}

This study analysed the tense in Kurdish using the tense categorical feature adopted by Benmamoun (2000) for the analysis of Arabic. It proposed that in the present tense in Kurdish, tense is specified only for [+D] feature, while the past and future have the $[+\mathrm{V}]$ feature and the $[+\mathrm{D}]$ feature. It introduced arguments in favour of these propositions. The present tense sentences are considered verbal not nominal because they show the characteristics of verbal constructions. Different arguments are presented in favour of this claim which are the identification of person, negation, their own present tense interpretation when they are embedded under a tensed matrix clause and that Kurdish verb to be has no present form. Following Rapoport (1987), it is argued that the agreement on the predicate can assign nominative case to the subject because the agreement is part of the predication relation.

The present study contributes to resolve the existent debate in Kurdish linguistics concerning the nature of these constructions. It provides evidences that verbless sentences in Kurdish are verbal sentences not nominal. Additionally, it contributes to the typological variation in the syntactic properties of these constructions in Kurdish.

\section{References:}

1. Abu-Joudeh, M. (2013). Case checking in verbless sentences functioning as embedded clases in Modern Standard Arabic: a minimalist account. In Theory and practice in language studies, Vol. 3, No. 2, pp 209-221.

2. Al-Horais, N. (2006). Arabic verbless sentences: is there a null VP? In Pragmalinguistica, 14. pp 101-116.

3. Amin, W. O. (1976). Some Fundamental Rules of Kurdish Syntax Structure. London.

4. Benmamoun, E. (2000). The feature structure of functional categories: a comparative study of Arabic dialects. Oxford: Oxford University press.

5. Chomsky, N. (1995). The minimalist program. Cambridge: The MIT press.

6. Hazout, I. (2010). Verbless Sentences and Clause Structure. In Linguistic Inquiry, Vol. 41, No. 3, pp. 471-485.

7. Fassi-Fehri, A. (1993). Issues in the structure of Arabic clauses and words. Kluwer: Dordrecht.

8. Hasan, A. M. (2012). Kurdish intonation with reference to English. Unpublished $\mathrm{PhD}$ thesis. University of Ulster, UK.

9. Hazout, I. (2010). Verbless Sentences and Clause Structure. Linguistic Inquiry, Vol. 41, No. 3, pp. 471-485. 
10. Mohammed, M. (1974). wirdbunewe le çend basiki rêzmanî kurdî (a brief overview of some topics in Kurdish grammar). Baghdad: Kurdish Scientific Group Press.

11. Rapoport, T. R. (1987). Copula, nominal and small clauses: a study of Israeli Hebrew. Unpublished $\mathrm{PhD}$ thesis. Massachusetts Institute of Technology.

12. Thackston, W. M. (2006). Kurmanji Kurdish: A reference grammar with selected readings. Retrieved from http: //www.fas.harvard.edu/Iranian/kurmanji/kurmanji-complete.pdf/.

13. Wetzer, H. (1996). The typology of adjectival predication. Berlin: Mouton de Gruyter. 
Appendix: List of Kurdish transliteration

\begin{tabular}{|c|c|c|c|c|c|}
\hline \multirow{2}{*}{ Arabic } & \multicolumn{2}{|c|}{ NK Latin } & \multirow[t]{2}{*}{ IPA Sound } & \multirow[t]{2}{*}{ Example } & \multirow[t]{2}{*}{ Meaning } \\
\hline & Capital & Small & & & \\
\hline 1 & A & $\mathrm{a}$ & /a:/ & av /a:v/ & (water) \\
\hline ب ب ب & B & $\mathrm{b}$ & $/ \mathrm{b} /$ & bîr /bi:r/ & (well) \\
\hline ج & $\mathrm{C}$ & c & $/ d z /$ & can /dza:n/ & (beautiful) \\
\hline בج & Ç & ç & $/ \mathfrak{t} /$ & çav /tfa:v/ & (eye) \\
\hline د & $\mathrm{D}$ & $\mathrm{d}$ & $/ \mathrm{d} /$ & dar /da:r/ & (tree) \\
\hline 。 & $\mathrm{E}$ & $\mathrm{e}$ & /a/ & ez /az/ & (I) \\
\hline يقى & $\hat{\mathrm{E}}$ & $\hat{\mathrm{e}}$ & $/ \mathrm{e}: /$ & êvar/e:va:r/ & (evening) \\
\hline ف ف & $\mathrm{F}$ & $\mathrm{f}$ & /f/ & freh /frah/ & (wide) \\
\hline s & G & $\mathrm{g}$ & $/ g /$ & germ /garm/ & (hot) \\
\hline ه & $\mathrm{H}$ & $\mathrm{h}$ & $/ \mathrm{h} /$ & helat /hala:t/ & (sunrise) \\
\hline$\tau$ & $\ddot{\mathrm{H}}$ & $\ddot{\mathrm{h}}$ & $/ \mathrm{h} /$ & ḧemîd /hami:d/ & (name of a person) \\
\hline ي & Î & $\hat{\imath}$ & /i:/ & îmarat /i:ma:ra:t/ & (Emirates) \\
\hline not written & I & $\mathrm{i}$ & /i/ & dil /dil/ & (heart) \\
\hline j & $\mathrm{J}$ & $\mathrm{j}$ & $\mid 3 /$ & jiyan /zija:n/ & (life) \\
\hline 5 & $\mathrm{K}$ & $\mathrm{k}$ & $/ \mathrm{k} /$ & kew /kaw/ & (dove) \\
\hline J & $\mathrm{L}$ & 1 & $/ 1 /$ & leŝ /laj/ & (body) \\
\hline ل & $\mathrm{L}^{\prime}$ & $1^{\prime}$ & $/ 1 /$ & sal' /sa:1/ & (year) \\
\hline 5 & M & $\mathrm{m}$ & $/ \mathrm{m} /$ & $\mathrm{mam} / \mathrm{ma}: \mathrm{m} /$ & (uncle) \\
\hline ن & $\mathrm{N}$ & $\mathrm{n}$ & $/ \mathrm{n} /$ & nan /na:n & (bread) \\
\hline وّ & $\mathrm{O}$ & o & $/ \mathrm{o} /$ & roĵ/roz/ & (day) \\
\hline 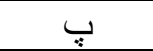 & $\mathrm{P}$ & $\mathrm{p}$ & $/ \mathrm{p} /$ & pîr /pi:r/ & (old) \\
\hline ق & Q & q & /q/ & qela /qala:/ & (castle) \\
\hline$\jmath$ & $\mathrm{R}$ & $\mathrm{r}$ & $/ \mathrm{s} /$ & bira /bira:/ & (brother) \\
\hline ر & $\overline{\mathrm{R}^{\prime}}$ & $\mathrm{r}^{\prime}$ & $/ \mathrm{r} /$ & r'ast /ra:st/ & (right) \\
\hline س س & $\mathrm{S}$ & $\mathrm{s}$ & $/ \mathrm{s} /$ & ser/sar/ & (head) \\
\hline ش & Ş & ş & $/ \mathrm{d} /$ & şans / Jans/ & (luck) \\
\hline$b$ & Ț & ţ & $/ \mathrm{t} /$ & ţa /ța:/ & (branch) \\
\hline$ت$ & $\mathrm{~T}$ & $\mathrm{t}$ & $/ \mathrm{t} /$ & te /ta/ & (you) \\
\hline 9 & $\mathrm{U}$ & $\mathrm{u}$ & $/ \mathrm{u} /$ & Kurd /kurd/ & (Kurd) \\
\hline وو - مو & $\hat{\mathrm{U}}$ & $\hat{\mathrm{u}}$ & /u:/ & bŭn /bu:n/ & (birth) \\
\hline ث & V & $\mathrm{v}$ & $/ \mathrm{v} /$ & viyan /vija:n/ & (love) \\
\hline 9 & $\mathrm{~W}$ & $\mathrm{w}$ & $/ \mathrm{w} /$ & war /wa:r/ & (home) \\
\hline$\dot{\tau}$ & $\mathrm{X}$ & $\mathrm{x}$ & $/ \mathrm{x} /$ & xelk/xalk/ & (people) \\
\hline$\dot{\varepsilon}$ & $\ddot{\mathrm{X}}$ & $\ddot{\mathrm{x}}$ & $/ \mathrm{\gamma} /$ & ẍem /yam/ & (sadness) \\
\hline ي & $\mathrm{Y}$ & $\mathrm{y}$ & $/ \mathrm{j} /$ & yar /ja:r/ & (beloved) \\
\hline j & $\mathrm{Z}$ & $\mathrm{z}$ & $|z|$ & zer /zar/ & (yellow) \\
\hline$\varepsilon$ & $E^{\prime}$ & $\mathrm{e}^{\prime}$ & /द/ & e'ard / / ard/ & (land) \\
\hline
\end{tabular}

